\title{
Observations on floral diversity including Lampen flora from the Borra Caves of Visakhapatnam district, Andhra Pradesh.
}

\author{
G.M.Narasimha Rao \\ Department of Botany, Andhra University, Visakhapatnam
}

\begin{abstract}
Caves are the natural formations with unique features for the growth and development of various species of flora and fauna. Further they provide the shelter for many biological organisms. In the recent years the scenario was changed due to installation of artificial illumination to attract the tourists and altered the physico-chemical features of the Caves. Borra caves are the beautiful natural cave with artificial illumination. Present communication deals with flora of various groups including Lampen flora which inhabit in different regions of the caves. Field trips were carried out for a period of one year from April 2015 to March 2016. Near the entrance of the cave five species of Bryophytes, four species of Pteridophytes, one species of Crustose Lichen and 10 species of algae were recorded. 12 species of Lampen flora were identified in dark zone of the cave where it is illuminated by artificial light during the day time. They appears as blue green, dark brown or black patches on the surfaces of rocks near the illuminated regions. Among the Lampen flora, Cyanophyceae species were more dominant than the members of the Chlorophyceae and only one species of Bacillariophyceae was recorded in this study.
\end{abstract}

Key words: Floral diversity, Lampen flora, Borra caves, Eastern Ghats of India.

\section{Introduction}

Caves are interesting and have a special place in human history and many caves are inscribed on the United Nations Educational, Scientific and Cultural Organization (UNESCO) World Heritage List. In the recent years many caves have experienced with intensified tourist visits further artificial illumination (in Borra caves also) was installed which changed physico-chemical features of the caves. At the entrance of the caves algae compete for light with other flora such as bryophytes and ferns (Round, 1981). Caves generally have constant temperature, low light and high humidity throughout the year ( $\mathrm{L} \mathrm{a} \mathrm{mp} \mathrm{r} \mathrm{i} \mathrm{n} \mathrm{o} \mathrm{u} \mathrm{et.} \mathrm{al.} \mathrm{2009).} \mathrm{Caves} \mathrm{are} \mathrm{having}$ three particular zones i.ethe entrance region, which is exposed to sunlight second one twilight region and the third one is the dark region, where no light penetrates .Biota of the caves able to adopt the extreme conditions to cope with the cave environmental features. ( $\mathrm{L} \mathrm{a} \mathrm{mp} \mathrm{r}$ i $\mathrm{n}$ ou et al. 2012). From lower to higher group of plants were occur based on their adaptation ( Mulec and Kosi, 2009). Aerophytic Cyanobacteria and few species of green algae acclimatized to dry and high desiccated atmosphere (Pentecost, 1992; Hoffman,1989). The Borra caves are natural caves situated near Aruku valley of the Eastern Ghats of India. Up to late 90s there was no artificial illumination inside the caves, only bats (may be some other fauna) are residing inside the caves. But, today these caves are illuminated with artificial light (Fig.1). Haraprasad Bairagya (2014) studied the environmental conditions of the Borra caves. Arunima Karkun and Seema Varma (2016) studied the fungal diversity of Borra caves. So in the present investigation, an attempt was made to investigate the distribution of flora such as algae, bryophytes, pteridophytes and other lichens including Lampen flora present in different regions of the Borra caves.
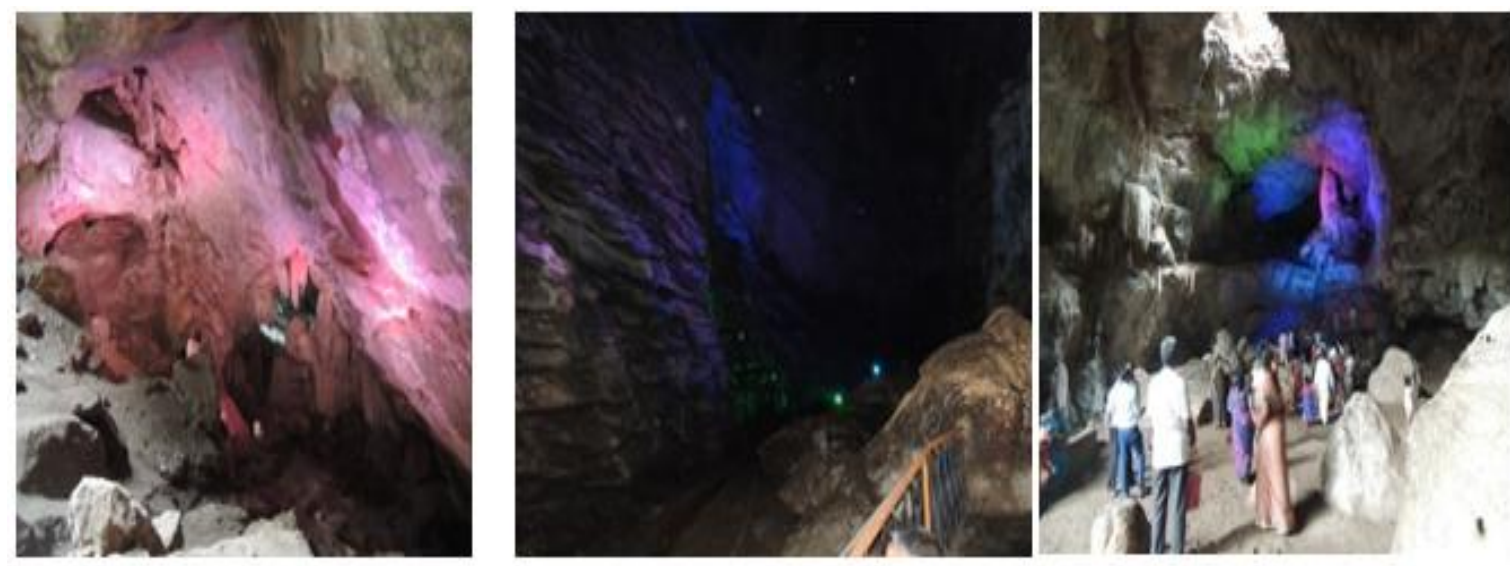

Figure 1. Pictures shows the artificial illumination inside the caves 


\section{Study Sites And Methods}

The Borra caves are located in the Anathagiri Mandal of Eastern Ghats of India. And lies between latitude of $18^{\circ} 10^{\prime} \mathrm{N}$ and the longitude of $83^{\circ} 0^{\prime} \mathrm{E}$. These caves are situated $92 \mathrm{~km}$ away from the Visakhapatnam and lies $3000 \mathrm{ft}$ above the sea level. These caves spread over one square kilometer area and the river Gosthani flows through the Borra caves (Fig.2). Field trips were conducted for period a one year from April 2015 to March 2016. Observations were made in three seasons of the study period. Samples were collected in different parts of the cave. Algal crusts were scraped from the walls and cervices using a scalpel and were placed in eppendrof tubes using scalpel and needles and brought them to the laboratory at Visakhapatnam. Algal samples were initially identified and then cultured them on solid agar medium. They were incubated in a BOD growth chamber at $20^{\circ} \mathrm{C}$ temperature with $9 \mu \mathrm{mol} . \mathrm{m}^{2} \mathrm{~s}^{1}$ light intensity for 8 hours during 0900 to 1700 hours. After one week these materials were identified with help of the monographs and manuals (Desikachary, 1959 and Komárek and Anagnostidis, 1999, 2005). Remaining samples such as Bryophytes, Pteridophytes and Lichens were identified with help of the deposited specimens at Herbarium of the Botany Department, Andhra University.

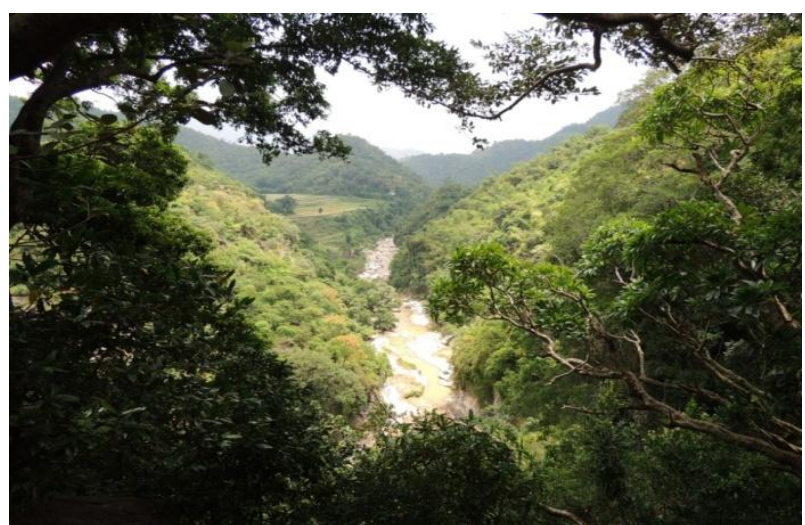

Figure 2. River Gosthani flows through the Borra caves
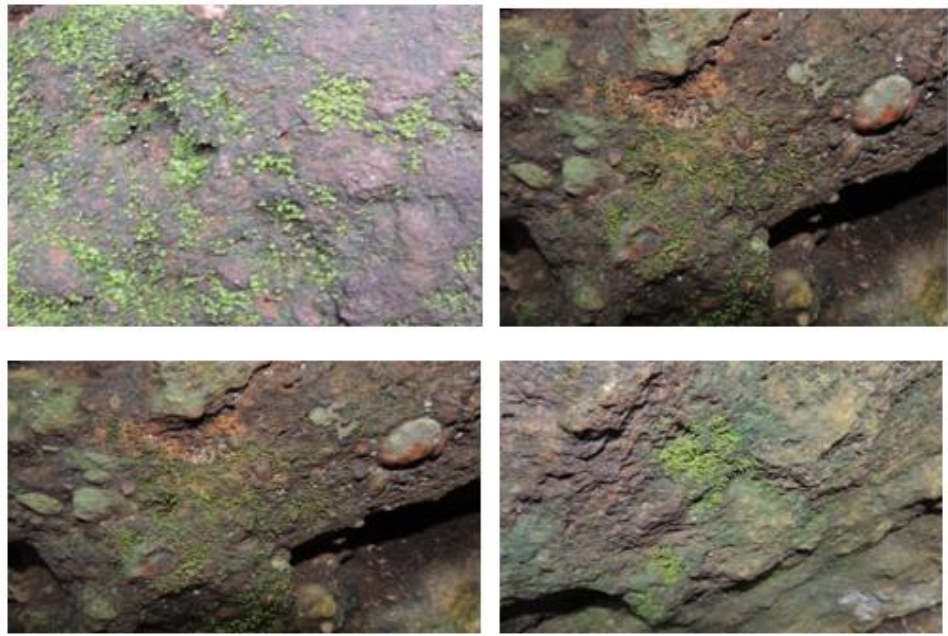

Figure 3. Species of Bryophytes and Pteridophytes on rocky surfaces of the caves near the entrance
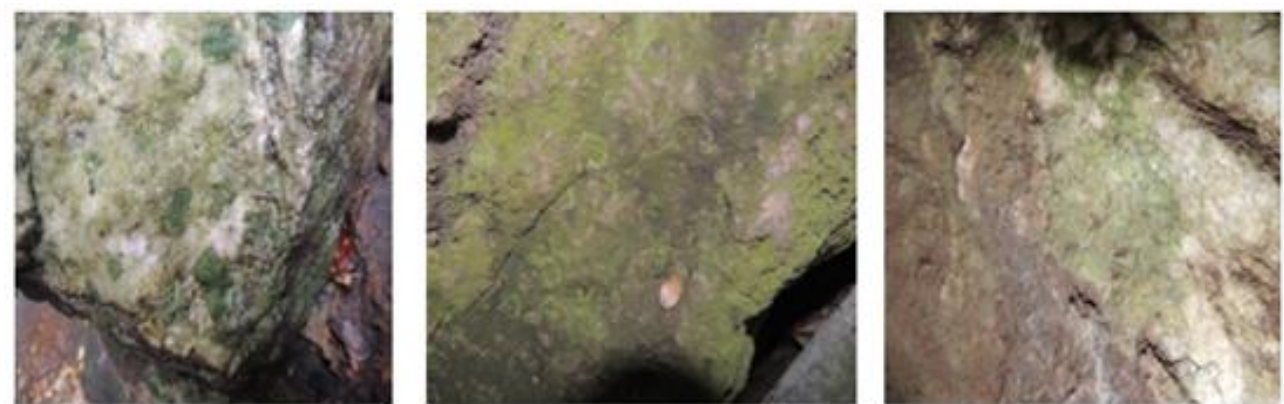

Figure 4. Crustose Lichens 


\section{Results And Discussion}

Information on environmental features such as air temperature, humidity and rainfall at Borra region were collected from Meteorological centre, Visakhapatnam. Air temperature in the Borra village varied from 18 to $34^{\circ} \mathrm{C}$, humidity ranged from 71 to $98 \%$ and rainfall varied from 32 to $312 \mathrm{~mm}$ during April 2015 to March 2016. Inside the caves temperature varied 16 to $19^{\circ} \mathrm{C}$ only. Species of algae to Pteridophytes and lichens were observed in different regions of the Borra caves. Caves are generally extreme environments with low amount of organic matter (Pedersen, 2000). So it may be limiting factor for so many groups of organisms, but some species survive and colonize successfully in the caves ( Dobat, 1970).

Table 1. List of the Bryophytes and pteridophytes present near the entrance (inside the caves)

\begin{tabular}{|l|l|l|l|}
\hline S.No & Name of the species & Family & Division \\
\hline 1 & Funaria hygrometrica. & Funariaceae & Bryophytes \\
\hline 2 & Funaria leptpoda & Funariaceae & Bryophytes \\
\hline 3 & Polytrichum alpinum & Polytrichaceae & Bryophytes \\
\hline 4 & Polytrichum densiflorum & Polytrichaceae & Bryophytes \\
\hline 5 & Spagnum cymbifolium. & Spagnaceae & Bryophytes \\
\hline 6 & Hemionitis arifolia & Adiantaceae & Pteridophytes \\
\hline 7 & Lygodium flexiosim & Schizaceae & Pteridophytes \\
\hline 8 & Lygodium scandens & Schizaceae & Pteridophytes \\
\hline 9 & Selaginella involvense & Selaginellaceae & Pteridophytes \\
\hline
\end{tabular}

Table 1 and Figs $3 \& 4$ shows the flora of Bryophytes and Pteridophytes present near the entrance of the caves. On the rocky surfaces of the cave, a total of 9 species were reported out of these species five species belongs to Bryophytes and remaining four belongs to Pteridophytes. Studies on distribution and density of cryptogams were conducted by few researchers in Visakhapatnam district (Narasimha Rao and Lohitasyudu, 2012; Narasimha Rao and Dora 2012). In their studies they have collected the quantitative data on the flora of Bryophytes and Pteridophytes. But, in the present study only qualitative data was collected due to presence of the minimum quantity of plant populations. Further, Crustose lichens such as Dirinaria applanata was observed in the cave.

Table 2. List of the aerophytic algae present near the Cave entrance

\begin{tabular}{|l|l|l|l|}
\hline S.No & Name & Family & Class \\
\hline 1 & Mesotaenium sps & Mesotaeniaceae & Chlorophyceae \\
\hline 2 & Chlorella sps. & Chlorellaceae & Cholorophyceae \\
\hline 3 & Trentepohila sps & Trentepohiliaceae & Chlorophyceae \\
\hline 4 & Desmococcus sps. & Chaetophoraceae. & Chlorophyceae \\
\hline 5 & Pleurococcus sps & Chaetophoraceae & Chlorophyceae \\
\hline 6 & Lyngbya sps. & Oscillatoriaceae & Cyanophyceae \\
\hline 7 & Nostoc sps. & Nostocaceae & Cyanophyceae \\
\hline 8 & Phormidium sps. & Oscillatoriaceae & Cyanophyceae \\
\hline 9 & Plectonema sps. & Oscillatoriaceae & Cyanophyceae \\
\hline 10 & Pinnularia sps & Pinnulariaceae & Bacillariophyceae \\
\hline
\end{tabular}

Table 2 shows the list of the aerophytic algae observed near the entrance, where cave is illuminated with diffused sunlight. A total of 10 algal forms were identified, out of these five belongs to Chlorophyceae, four belongs to Cyanophyceae and remaining one is member of the Bacillariophyceae. Algae successfully grow in different habitats such as fresh, marine and estuarine waters, besides algae can tolerate the unusual habitats like hot water springs, alpine regions, on the barks of the trees and inside the caves. In caves two distinct habitats with different illuminations. One is with (entrance of the cave) illuminated by partial sunlight/ diffused sunlight during the day time. While another habitat (inside the cave) with artificial sunlight which favours the growth of the some Cyanobacteria. Narasimha Rao (2017) collected the information on the aerophytic algae present on the barks of the large trees. In that paper author reported 12 algal forms on the barks of the big trees.

Table 3. List of the Lampen flora present in Borra caves.

\begin{tabular}{|l|l|l|l|}
\hline S.No & Name & Family & Class \\
\hline 1 & Aphanocapsa sps. & Chroococcaceae & Cyanophyceae \\
\hline 2 & Chroococcus sps. & Chroococcaceae & Cyanophyceae \\
\hline 3 & Gloeocapsa sps. & Chroococcaceae & Cyanophyceae \\
\hline 4 & Lyngbya sps. & Oscillatoriaceae & Cyanophyceae \\
\hline 5 & Nostoc sps. & Nostocaceae & Cyanophyceae \\
\hline 6 & Phormidium sps. & Oscillatoriaceae & Cyanophyceae \\
\hline 7 & Plectonema sps. & Oscillatoriaceae & Cyanophyceae \\
\hline 8 & Pinnularia sps. & Pinnulariaceae & Bacillariophyceae \\
\hline 9 & Chlorella sps. & Chlorellaceae & Chlorophyceae \\
\hline
\end{tabular}




\begin{tabular}{|l|l|l|l|}
\hline 10 & Desmococcus sps. & Chaetophoraceae. & Chlorophyceae \\
\hline 11 & Trentepohila sps & Trentepohiliaceae & Chlorophyceae \\
\hline 12 & Mesotaenium sps & Mesotaeniaceae & Chlorophyceae \\
\hline
\end{tabular}
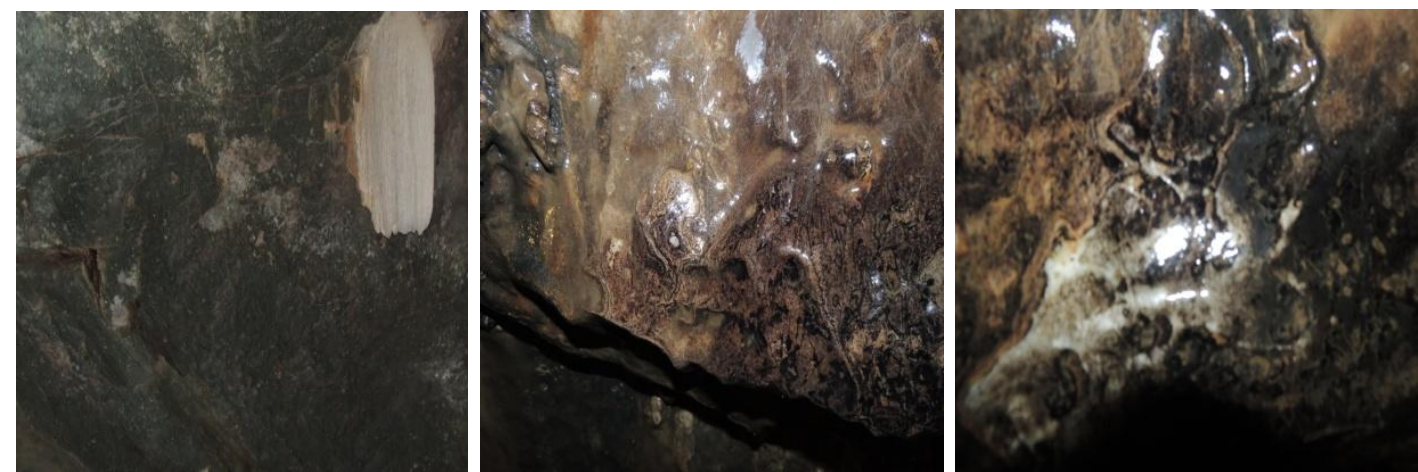

Fig. 5 Brown and black patches with members of the Cyanophyceae

Fig 5 shows the patches of blue green, dark brown and black areas predominantly present inside the caves which consists the Blue green algal forms. Table 3 shows the 12 species of Lampen flora. Out these, 7 species belongs to Cyanophyceae and 4 species belongs to Chlorophyceae and remaining one is Bacillariophyceae member. Near the cave more Chlorophyceae members were recorded than the other groups while in the dark zone more Cyanophyceae were observed than the remaining groups. Further investigations on the nutrients levels in the caves, chlorophyll content and impact of the light intensity on the growth and development of the Lampen flora as well as other groups will help to understand the biology of the cave flora.

\section{References}

[1]. Arunima Karkun and Seema Varma, 2016. Study and survey of Fungal diversity of Borra caves situated in Andhra Pradesh, India. International Journal of Research in Ayurveda and Pharmacy 7 (2): 241-246.

[2]. Desikachary, T.V. 1959. Monograph on Cyanophyta, I.C.A.R. New Delhi.

[3]. Dobat, K., 1970, Conside'rations sur la ve'ge'tation cryptogamique des grottes du Jura Souabe (sud-ouest de l'Allemagne): Annales de Spe'le'ologie, v. 25, no. 4, p. 872-907.

[4]. Haraprasad Bairagya 2014. Environmental conditions of Borra cave, Visakhapatnam,India.

[5]. International Journal of Environment, Vol. 3 (2) 150-166.

[6]. Hoffman, L. 1989. Algae of terrestrial habitats. The Botanical Review 55:77-105.

[7]. Komárek, J. and Anagnostidis, K. 2005. Cyanoprokaryota, II. Teil Oscillatoriales, Band 19/2, Süßwasserflora von Mitteleuropa, Elsevier GmbH, Munchen, 759 pp.

[8]. La mpr i nou V., P a nt a z ido u A ., P a p a d og i a n n a k i G., R a d e a C ., E c onomou-Ami 11 i A .2009. Cyanobacteria and associated invertebrates in Leontari Cave, Attica (Greece). Fottea 9(1): 155-164.

[9]. La mpr i nou V., D a n i e 1 id i s D.B., E c onomou-Am i 11 i A ., P a n t a z i d o u A . 2012. Distribution survey of Cyanobacteria in three Greek caves of Peloponnese.Inter. Jour. of Spel., 41(2): 267-272.

[10]. Mu l e c J ., Ko s i G. 2008. Algae In the aerophytic habitat of Račiške ponikve cave (Slovenia). Natura Sloveniae 10(1): 39-49.

[11]. Narasimha Rao, G.M. and Lohitasyudu,K. 2012.Distribution and species abundance of pteridophytic flora of G.Madugula Mandal, Visakhapatnam District, Andhra Pradesh, India. IJBPAS 1 (5): 730-736

[12]. Narasimha Rao,G.M. Dora SVVSN.2012 Distribution and abundance of Bryophytes at Dhaaramatam, Visakhapatnam district, Andhra Pradesh. IJBPAS, Vol. 1(11): 1730-1733.

[13]. Narasimha Rao ,G.M. 2017. A preliminary survey on corticolous algae from Gangaraju Madugula forest region, Eastern Ghats of India. Andhra Pradesh. Algal Biomass Utln. 2017, 8(1): 45-47.

[14]. Pentecost A. (1992): A note on the colonization of limestone rocks by cyanobacteria. - Arch. Hydrobiol. 124:167-172.

[15]. Pedersen, K., 2000, Exploration of deep intraterrestrial microbial life: current perspective. MiniReview: FEMS Microbiology Letters, v. 185, p. 9-16.

[16]. Rou n d F.E. 1981. The ecology of algae. Cambridge University Press, Cambridge, London, New York, New Rochelle,Melbourne, Sydney, 1-653. 